\title{
Study of Groundwater Quality in Concern with Fluoride of Village Rampur from Ghatanji Tehsil, Yavatmal, Maharashtra (India)
}

\author{
Sanjay G Chandne \\ Asst Professor. Department of Civil Engineering, Jawaharlal Darda Institute of Engg and Technology, \\ Yavatmal. (M.S) India.
}

\begin{abstract}
Ground water analysis has been carried out in Rampur village using hydrogeological analysis aspects in a systematic way by utilizing various physio-chemical analysis and statistical techniques. This study will also provide first hand information on fluoride problem in water and geology of the study area. This study will also provide the knowledge about the hydrogeology of the area. Fluorosis disease comes from the increasing percentage of fluoride minerals present in the rocks or subsoil region. People use the water for drinking purposes and through this the percentage of fluoride increases into the body and results into the fluorosis disease in the habitat. For knowing the origin or source of the fluorosis problem it is very important to know about the geology and hydrological properties of the rocks, also analyses the physio- chemical characteristic of ground water.

Keywords: Water quality, Fluoride, Groundwater, Strata, Rocks, Fluorosis.
\end{abstract}

\section{Introduction:}

Maharashtra is the third largest state (30.8 million hectares) with the third largest population (97 million) in India. About 58\% of the state's population is in rural areas, $80 \%$ of whom are dependent on agriculture for their livelihood. The rural poverty rate is about 32\% (1999/2000). Poverty rates are very high among cultivators and agricultural labourers (23\% and $57 \%$ headcount respectively). The availability of water in the state is highly uneven, both spatially and temporally; most of the rainfall occurs in just 40 to 100 days. The ultimate irrigation potential of the state is about 12.6 million hectare $(\mathrm{m} \mathrm{ha})$, of which $8.5 \mathrm{~m}$ ha is from surface water and $4.1 \mathrm{~m}$ ha from ground water sources [E.B Patil and Dr Sanjay Belsare;2012].

In this Maharashtra State the Yavatmal district, bordering Andhra Pradesh, having a incidence of fluorosis has been raising in recent years alongside the mindless extraction of groundwater. Lack of rainfall has meant that the district is largely dependent on groundwater, both for irrigation and drinking water requirements. Incessant digging of bore wells has given rise to sharp rise in the fluoride concentration in the ground water. Fluorides and other dissolved salts in drinking water have exceeded the safe limit in the past two decades. A high intake of fluoride $(>1.5 \mathrm{mg} / \mathrm{l})$ in drinking water over a prolonged period is known to cause damage to the enamel of the teeth, and eventually results in skeletal complications leading to fluorosis [Chavan $N$ K;2012]. A progressively increasing proportion of the population in Yavatmal including undernourished children is now infected with fluorosis. Fluoride concentration of at least $0.6 \mathrm{mg} / \mathrm{l}$ is required for human consumption as it will help to have stronger teeth and bones. Consumption of water with fluoride concentration above $1.5 \mathrm{mg} / \mathrm{l}$ results in acute to chronic dental fluorosis where the tooth become coloured from yellow to brown. Skeletal fluorosis which causes weakness and bending of the bones also results due to long term consumption of water containing high fluoride. Rural populations, which depend mainly on groundwater for their drinking water supply are the worst affected. Vulnerability to fluorosis is higher if the nutritional status is poor-malnourished children, pregnant women or lactating mothers are especially vulnerable [Anuradha Kumar;2002].

\section{Study Area:}

The area under study fall in Yavatmal district, in Ghatanji Tq. situated in S-E part of the Yavatmal city nearly $40 \mathrm{~km}$. away. The longitude of study area is $78^{\circ} 32^{\prime}$ to $78^{\circ} 36^{\prime}$ and latitude is $20^{\circ} .04$ to $20^{\circ} .08^{\prime}$ which include in map of survey of India toposheet No. 55 L/12. The village Rampur lies in the way of village Khadka To Arni road.The study area lies in adjoining to the Rampur. The villages are as follows -Ramnagar, Ghoti, Shiroli, Amadi, Manoli, Rahati etc.

\section{General Geology of the area:}

The degradation of groundwater may be due to natural or anthropogenic processes.

Anthropogenic sources include agricultural fertilisers and combustion of coal. Phosphate fertilisers contribute 
to fluoride in irrigation lands. Coal which is a potential source of fluoride is used for combustion in various industries and in brick kilns. Also fluorine is highly reactive and is found naturally as CaF2.It is an essential constituent in minerals like topaz, fluorite, fluorapatite, cryolite, phosphorite, theorapatite, etc[Brinda.K and Elango.L;2011]. The fluoride is found in the atmosphere, soil and water. It enters the soil through weathering of rocks, precipitation or waste run off. Fluorine is widely spread in nature and is a common constituent of most soils and rocks, plants and animals. It is the 13th most abundant element, averaging $650 \mathrm{mg} / \mathrm{L}$ in the earth crust. In groundwater, the natural concentration of fluoride depends on the geological, chemical and physical characteristics of the aquifer, the porosity and acidity of the soil and rocks, temperature, the action of other chemicals and the depth of wells. Due to large number of variables, the fluoride concentrations in groundwater range from well under $1.0 \mathrm{mg} / \mathrm{L}$ to more than 35.0 mg/L[Meenakshi and RCMaheshwari;2006].

\section{Impact of Fluoride :}

Fluorine being a highly electronegative element has extraordinary tendency to get attracted by positively charged ions like calcium. Hence the effect of fluoride on mineralized tissues like bone and teeth leading to developmental alternations is of clinical significance as they have highest amount of calcium and thus attract the maximum amount of fluoride that gets deposited as calcium-fluorapatite crystals. Tooth enamel is composed principally of crystalline hydroxylapatite. Under normal conditions, when fluoride is present in water supply, most of the ingested fluoride ions get incorporated into the apatite crystal lattice of calciferous tissue enamel during its formation. The hydroxyl ion gets substituted by fluoride ion since fluorapatite is more stable than hydroxylapatite [Meenakshi and RCMaheshwari;2006].

The study area comes under Yavatmal dist. of Maharashtra. It includes Deccan trap basalt. The visually interpreted geological frame work of the area comprises of Archean gneisses, Gondwana sequence and basaltic flows [Chavan $N$;2012]. The generalized stratigraphic succession of the area is as shown below:

\begin{tabular}{|c|c|c|c|}
\hline Age & Group & Formation & Lithology \\
\hline Quaternary & & & Alluvium \\
\hline \multirow[t]{4}{*}{$\begin{array}{l}\text { Cretaceous } \\
\text { to Paleocene }\end{array}$} & \multirow{4}{*}{$\begin{array}{l}\text { Sahayadri } \\
\text { Group }\end{array}$} & \multirow{2}{*}{$\begin{array}{l}\text { Karanja } \\
\text { Formation }\end{array}$} & 2 to 5 flows ( $160 \mathrm{~m}$ thick) \\
\hline & & & Aa flows (50m thick) \\
\hline & & $\begin{array}{l}\text { Chikali } \\
\text { Formation }\end{array}$ & 11 aa and 1 compound flows $(90 \mathrm{~m}$ thick) \\
\hline & & $\begin{array}{c}\text { Ajanta } \\
\text { Formation }\end{array}$ & $\begin{array}{c}5 \text { aa and } 9 \text { pahoehoe flows (154m } \\
\text { thick) }\end{array}$ \\
\hline $\begin{array}{l}\text { Permian to } \\
\text { Triassic }\end{array}$ & $\begin{array}{l}\text { Gondwana super } \\
\text { Group }\end{array}$ & Moture formation & Sandstone \\
\hline
\end{tabular}

\section{Methodology of study:}

The method of work can be divided in two parts. First is the field work and another is laboratory work. The field works have been done in various villages mention in the above para i:e The villages are as follows Ramnagar, Ghoti, Shiroli, Amadi, Manoli, Rahati etc. of Ghatanji tehsil of Yavatmal district. The samples were collected since from the month of September 2013 to November 2013 at various locations of the mention villages. The samples were collected in air tight bottle and sealed by giving the sample number on bottle as shown in table no -1. After collecting the samples we have to do chemical analysis in our department's laboratory, Such as pH, Alkalinity, Conductivity, TDS(Total dissolved solids), Nitrate and above all Fluoride, etc. Collect the sample from Pub-well, HP after completion of well inventory data followed by physical quality parameter, analyzed collected water sample. Results after the physio- chemical analysis of water sample is given below in table no -1 . Following are the analysis has done to found the parameters from the water samples.

\section{Water Testing Method.}

Water testing requires the following mechanism to be followed:

1. Samples collection

2. Physical Test

3. Chemical Test

\section{Sampling Process}

- Burn a piece of paper and keep the flame at the mouth of the hand pump and the water pipe for few seconds. It kills the bacteria present on surface. Operate the hand pump for 4-5 minutes

- Once water stream flows freely, wash your hands and the sample bottle properly. 
- $\quad$ Fill $80 \%-90 \%$ of the bottle with sample water. Close the bottle tightly.

- Label the sample bottle with source, location, date and time.

Physical test includes

Taste (Using your tongue).Color (By looking at the color of water). Odor (By smelling the sample water).

Transparency / Turbidity (By looking for the clarity of water). Temperature (measured using thermometer).

Chemical test includes

\# pH Test (Test with Litmus Paper). \#TDS (Total Dissolved Solids) TEST. \# FLOURIDE TEST. \# NITRATE TEST.

Table no -1 showing the Physio-chemical data of the water samples collected at village Rampur and nearby area of Ghatanji Tehsil of Yavatmal District , Maharashtra.

\begin{tabular}{|c|c|c|c|c|c|c|c|c|c|}
\hline SI. No. & Sample & Village / Wadi & Source & Location & $\mathbf{F}$ & $\begin{array}{l}\text { Recent } \\
\text { testing }\end{array}$ & TDS & $\mathrm{pH}$ & NO3 \\
\hline 1 & 00R1 & Ramnagar & HP & $\begin{array}{l}\text { Near the Moran } \\
\text { Jadhav's house }\end{array}$ & 5.20 & Dry & 315 & 8.0 & 114 \\
\hline 2 & 00R2 & Ramnagar & HP & $\begin{array}{l}\text { In the farm of } \\
\text { Bhaian Rathod }\end{array}$ & 4.30 & 6.10 & 330 & 7.0 & 32 \\
\hline 3 & 00R3 & Ramnagar & HP & $\begin{array}{l}\text { Near the Pardhi } \\
\text { Beda }\end{array}$ & 5.00 & 7.00 & 580 & 8.5 & 12 \\
\hline 4 & 00R4 & Ramnagar & HP & $\begin{array}{l}\text { Near the Prayag } \\
\text { Motiram Chavan's house }\end{array}$ & 3.80 & 4.10 & 470 & 7.3 & 54 \\
\hline 5 & 00B1 & Bilayata Old & HP & $\begin{array}{l}\text { Near the Nagrale's } \\
\text { house }\end{array}$ & 3.75 & 4.95 & 655 & 7.2 & 2 \\
\hline 6 & 00B2 & Bilayata New & HP & $\begin{array}{l}\text { Near the M.G. Ukle's } \\
\text { house }\end{array}$ & 3.00 & 3.95 & 490 & 8.0 & 4 \\
\hline 7 & 00B3 & Bilayata New & HP & $\begin{array}{l}\text { Behind the Champat } \\
\text { Napte's house }\end{array}$ & 3.45 & 4.25 & 995 & 7.5 & 22 \\
\hline 8 & $00 \mathrm{M} 1$ & Manusdhari & MPWSS & $\begin{array}{l}\text { Near the Prakash } \\
\text { Sanganwar's house }\end{array}$ & 2.15 & 2.85 & 680 & 7.5 & 17 \\
\hline 9 & 00GW1 & $\begin{array}{l}\text { Ghoti Waghu } \\
\text { Pod }\end{array}$ & $\mathrm{HP}$ & Besides the road & 11.10 & 13.50 & 390 & 8.5 & 4 \\
\hline 10 & 00Rm & Rampur & HP & $\begin{array}{l}\text { In the Courtyard of } \\
\text { PHC Centre }\end{array}$ & 2.85 & 4.10 & 545 & 7.2 & 11 \\
\hline 11 & 0SH1 & Shiroli & HP & $\begin{array}{l}\text { In the Courtyard of } \\
\text { Dr. Tawar' house }\end{array}$ & 5.10 & 3.95 & 345 & 8.9 & 12 \\
\hline 12 & ORH1 & Rahati & HP & $\begin{array}{l}\text { Near Gram } \\
\text { Panchayat }\end{array}$ & 2.80 & 4.45 & 890 & 7.6 & 15 \\
\hline 13 & ORH2 & Rahati & $\mathrm{HP}$ & Near Chawadi & 3.30 & 3.85 & 880 & 7.8 & 13 \\
\hline 14 & OPN1 & Pangadi & $\mathrm{HP}$ & $\begin{array}{l}\text { Near the Bajrangbali } \\
\text { temple }\end{array}$ & 2.35 & 2.70 & 515 & 7.7 & 15 \\
\hline 15 & OPN2 & Pangadi & $\mathrm{HP}$ & Near the Road side & 5.35 & 7.10 & 670 & 8.1 & 35 \\
\hline 16 & $0 \mathrm{~A} 1$ & Amadi & MPWSS & $\begin{array}{l}\text { Near the Gram } \\
\text { Panchayat }\end{array}$ & 19.00 & Dry & 610 & 9.2 & 44 \\
\hline 17 & $0 \mathrm{GP1}$ & Ghoti pardhiBeda & $\mathrm{HP}$ & $\begin{array}{l}\text { Near house of Hajari } \\
\text { Ghosale }\end{array}$ & & 8.15 & 640 & 8.0 & 11 \\
\hline 18 & 0GR1 & Ghoti Ramnagar & $\mathrm{HP}$ & Near Anganwadi & & 6.45 & 640 & 8.3 & 23 \\
\hline 19 & OMN1 & Manoli & $\mathrm{HP}$ & Near Bus Stand & & 3.14 & 580 & 9.0 & 31 \\
\hline
\end{tabular}

\section{Conclusion of study:}

From the above project various conclusions are derived by our experiences during the field work.

- Fluoride is present in surface water as well as in subsurface water in the study area of Yavatmal district.

- Fluoride is presence due to fluoride content minerals occurring in soil and rock in the area.

- Fluorite $\left(\mathrm{CaF}_{2}\right)$ a common fluoride bearing mineral is present in the Precambrian crystalline in sedimentary rocks of the area.

- Fluorite generally occurs in irregular bedding replacement deposits especially in limestone.

- The apatite $\left(\mathrm{Ca}_{3} \mathrm{P}_{2} \mathrm{O}_{3} \mathrm{CaF}_{2}\right)$ Occurs in the form of crystals grain in basic igneous rocks such as basalts.

- Sometimes fluoride concentrates in pegmatitic metallic vein and magmatic intrusion in the Precambrian basement.

- It also occurs in metamorphic rock i.e. schist and gneisses. 
- The study area is covered by Flows belonging to Deccan traps, the shallow Precambrian basement.

- It is speculated that the circulating groundwater from the basement into the shallow aquifer is responsible for the concentration of fluoride in the groundwater sources of the area.

- Dental fluorosis is occurring due to increasing percentage of fluoride in water. PH value of water sample is higher in village Amadi of Rampur is $9.2 \mathrm{mg} /$ lit found in study area which is located near floor mill.

- Alkalinity value of water sample is higher in village Amadi, shiroli and manoli area is 400 $\mathrm{mg} /$ lit found in study area which is located near by places of the mention village.

- Chloride value of water sample is higher in Rampur is $334 \mathrm{mg} /$ lit found in study area which is located near neem tree.

- Fluoride value of water sample is higher in Amdi is $19.0 \mathrm{mg} / \mathrm{lit}$ found in study area which is located in school campus.

- Surface waters generally do not contain more than $0.3 \mathrm{mg} / \mathrm{L}$ of fluoride unless they are polluted from external sources. Though drinking water is the major contributor (75-90\% of daily intake), other sources of fluoride poisoning are food. Therefore, now there is a need to focus greater attention on the future impact of water resources planning and development taking into consideration all the related issues.

\section{References:}

[1]. Susheela, A.K., (2003) A Treatise on Fluorosis, revised $2^{\text {nd }}$ ed., New Delhi, India: Fluorosis Research and Rural Development Foundation.

[2]. A Gautam ,R C Tripathi : Fluoride Testing and Fluorosis Mitigation in Sonebhadra District. Research Scientist , People Science Institute ,Dehradoon.

[3]. SPS Teotia, M Teotia \& K R Singh, India Highlits of Forty Years of Research on Endemic Skeletal Fluorosis in India , 4 th International Workshop on Fluorosis Prevention \& Defluoridation of Water.

[4]. Meenakshi *, R.C. Maheshwari "Fluoride in drinking water and its removal" 2006. Journal of Hazardous Material ,16 Feb 2006 ,Published by Elsevier B.V.

[5]. Anuradha Kumar (2007) "Fluorosis in Yavatmal " Fluoride Action Network, 2007.

[6]. Chavhan N.K. "Groundwater Quality with Special Reference to Fluorosis of Konghara Dharana Region , District Yavatmal ,Maharashtra ,India”. International Journal of Science, Environment and Technology, Vol. 1, No 5, 2012,425 - 429

[7]. Bhagyashree M Mamilwar , A G Bhole \& A M Sudame "Removal of Fluoride from Groundwater By Using Adsorbent " IJERA, ISSN2248-9622,Vol-2, Issue-4,Juluy August 2012, pp 334-338.

[8]. Brindha, K. and Elango, L. "Fluoride in Groundwater: Causes, Implications and Mitigation Measures".(2011 In Monroy, SDCED),Fluoride Properties, Application and Environmental Management pp 111-136.

[9]. Pandith Madhnure, D. Y. Sirsikar, N. Tiwari, B. Ranjan and D. B. Malpe. "Occurrence of Fluoride in the Groundwaters of Pandharkawada Area, Yavatmal District, Maharashtra, India" Current Science vol -92, no- 5, 10 march 2007.

[10]. Mohammad Arif, S. Joshi , Sudesh Kumar "A Study of Fluoride Contaminated Ground Water in Uniara Tehsil, District- Tonk, Rajasthan, India".

[11]. Arif M, Hussain I, Hussain J, Sharma S, Kumar S (2012)"Fluoride in the Drinking Water of Nagaur Tehsil of Nagaur District, Rajasthan, India".

[12]. Arif M, Hussain J, Hussain I, Neyol S (2011)"Fluoride Contamination of Ground Water of Merta Block in Nagaur District, Rajasthan, India". In The conference of advance in Environmental chemistry (AEC),Aizwal, Mizoram, pp-146-148.

[13]. Ayoob, S., \& Gupta, A. K. (2006) "Fluoride in drinking water: A review on the status and stress effects". Critical Reviews in Environmental Science and Technology, 36, 433-487.

[14]. Hussain I, Arif M, Hussain J (2011) "Fluoride contamination in drinking water in rural habitations of Central Rajasthan, India".

[15]. Mohd. Arif, Husain I, Hussain J, S Kumar "Fluoride Distribution in Ground Water and Survey of Dental Fluorosis in Villages o Didwana Tehsil of Nagaur District of Central Rajasthan, India." India Water Week 2012 - Water, Energy and Food Security : Call for Solutions, 10-14 April 2012, New Delhi.

[16]. D.D. OZHA "Rising Nitrate and Fluoride Levels in Ground Water -A Challenge Ahead For Sustainable Health \& SocioEconomic Development of Rajasthan", India Water Week 2012 - Water, Energy and Food Security : Call for Solutions,

10-14 April 2012, New Delhi.

[17]. S P S Teotia, M Teotia and K P Singh India "Highlights of Forty Years of Research on Endemic Skeletal Fluorosis in India.

[18]. Ground Water Assessment development and Management: K. R. Karanth.

[19]. Water Resources and Hydrology: S.P. Garg. Evaluation and Development of Ground water: Gautam Mahajan.

[20]. Engineering and general Geology: Parbin Singh. Applied Hydrogeology: C.W. Fetter.

[21]. Report Of fluoride affected area: G.S.D.A. Yavatmal. 